\title{
STUDI MORFOMETRI DAN FAKTOR KONDISI SOTONG (Sepiella inermis: Orbigny, 1848) YANG DIDARATKAN DI PPI TAMBAKLOROK, SEMARANG
}

\author{
Nur Rochman, Haeruddin, Norma Afiati ${ }^{1}$ \\ Program Studi Manajemen Sumberdaya Perairan, Jurusan Perikanan \\ Fakultas Perikanan dan Ilmu Kelautan, Universitas Diponegoro \\ Email: success_nurrochman93@yahoo.co.id
}

\begin{abstract}
ABSTRAK
S. inermis merupakan spesies kompleks dan umumnya memiliki ukuran yang kecil dengan sirip yang sempit. S. inermis dapat ditemukan pada perairan dengan kisaran kedalaman 10-20 meter. Sifat pertumbuhan penting untuk dipelajari baik melalui studi panjang berat, faktor kondisi, dan morfometri karena dapat digunakan untuk upaya pengelolaan yang berkelanjutan. Penelitian ini menggunakan metode deskriptif dimana pelaksanaannya melalui teknik survei dan pengambilan sampel menggunakan metode systematic random sampling. Data yang digunakan adalah data panjang mantel (mm) dan berat (gram) dari S. inermis serta pengukuran beberapa variabel morfometri $(\mathrm{mm})$. Dari hasil penelitian hubungan panjang berat $S$. inermis mengikuti persamaan $\mathrm{W}=0,00129 \mathrm{~L}^{2,4978}$. Hal tersebut menunjukkan bahwa sifat pertumbuhan dari $S$. inermis adalah allometrik negatif. Itu berarti bentuk tubuhnya kurus dan pertambahan panjangnya lebih cepat dari pertambahan berat. Sementara itu berdasarkan hasil pengukuran morfometri menunjukkan variasi sifat pertumbuhan antara variabel-variabel yang diperbandingkan. Lengan memiliki kecepatan tumbuh yang lebih cepat dibandingkan dengan mata, kepala, dan tentakel. Hal itu karena peran lengan yang sangat penting dalam proses kehidupannya untuk menangkap dan menaklukkan buruannya.
\end{abstract}

Kata kunci : Sepiella inermis, Hubungan Panjang Berat, Faktor Kondisi, Morfometri

\begin{abstract}
S. inermis is a complex species and generally has a small size with narrow fins. S. inermis can be found in waters with a range of 10-20 meters depth. Groeth is important property to be studied, as well as length-weight, condition factor and morphometric features, because it can be used for sustainable management resources. This research uses descriptive method with implementation through surveys and sampling techniques using random sampling methods. The data used were mantle length $(\mathrm{mm})$ and weight (gram) of S. inermis along with morphometric measurements of all parts of the body which were possible to be measured accurately variables $(\mathrm{mm})$. The result showed that length-weight relationship of $\mathrm{S}$. inermis following this equation $\mathrm{W}=0.00129 \mathrm{~L}^{2,4978}$, means that the nature of the growth of $\mathrm{S}$. inermis was a negative allometric. It means the body is thin and increased in body length was faster than the weight gained. Meanwhile, fot which results of morphometric measurements showed allometric growth variation among the variables compared. The arms have grown faster than the eyes, head, and tentacles. This is because the arms are very important in the process of his life to catch and hunting predation.
\end{abstract}

Keywords : Sepiella inermis, Lenght Weight Relatioship, Condition Factor, Morphometric 


\section{Pendahuluan}

Cephalopoda merupakan salah satu kelompok binatang lunak yang tidak memiliki tulang belakang (Avertebrata). Beberapa jenis Cephalopoda memiliki nilai komersial dan merupakan salah satu sumberdaya hayati yang penting dalam sektor perikanan laut (Roper et al., 1984). Sudjoko (1988) menyatakan bahwa didalam dunia perdagangan, sebagian besar Cephalopoda dibedakan menjadi 3 (tiga) kelompok yaitu cumicumi (squid), sotong (cuttlefish), dan gurita (octopus). Setiap kelompok dapat terdiri dari satu suku (famili) atau lebih yang mempunyai arti ekonomi penting. Loliginidae, Onychoeteuthidae, dan Ommastrephidae, adalah suku-suku yang mendukung kelompok cumi-cumi. Adapun Sepiidae dan Octopodidae adalah sukusuku yang secara berurutan mendukung kelompok sotong (cuttlefish) dan gurita (octopus) (Djajasasmita et al., 1993).

Selama ini penangkapan sotong di Indonesia masih bergantung dari alam salah satunya karena sulit untuk dibudidayakan. Oleh karena itu dikhawatirkan sumberdaya perikanan ini akan menurun secara kualitas dan kuantitas, sehingga perlu dilakukan antisipasi dalam upaya konservasi secara hayati. Dalam melakukan upaya konservasi secara hayati ini maka diperlukan studi tentang biologi pertumbuhan sotong yang meliputi panjang berat, faktor kondisi, struktur populasi, dan morfometri. Dalam dunia perikanan informasi panjang berat, faktor kondisi dan morfometri pada Cephalopoda khususnya Cuttlefish penting diketahui dalam upaya pengelolaan sumberdaya perikanan khususnya di daerah Kota Semarang. Pengukuran panjang berat juga dimaksudkan untuk mengetahui variasi berat dan panjang tertentu dari ikan secara individual atau kelompokkelompok individu sebagai suatu petunjuk tentang gemuk, sehat, produktifitas dan kondisi fisiologis termasuk perkembangan gonad. Analisa panjang berat juga dapat mengestimasi faktor kondisi yang merupakan salah satu hal penting dari pertumbuhan untuk membandingkan kondisi atau keadaan kesehatan relatif populasi ikan atau individu tertentu (Merta, 1993).

Morfometrik adalah ciri yang berkaitan dengan ukuran tubuh atau bagian tubuh ikan misalnya panjang total dan panjang baku. Ukuran ini merupakan salah satu hal yang dapat digunakan sebagai ciri taksonomik saat mengidentifikasi ikan.Hasil pengukuran dinyatakan dalam satuan milimeter atau sentimeter, ukuran yang dihasilkan disebut ukuran mutlak (Affandi et al., 1992). S. inermis merupakan spesies kompleks dan umumnya memiliki ukuran yang kecil dengan sirip yang sempit. Ukuran maksimum panjang mantel $S$. inermis yaitu sekitar $125 \mathrm{~mm}$ (FAO, 2005). Mantel berwarna coklat keabu-abuan dengan delapan sampai sembilan lingkaran kecil kemerah-merahan sepanjang dasar masing-masing sirip, lebar cuttlebone kira-kira $40 \%$ dari panjangnya, bagian luar yang mengerucut dan menekuk kearah bagian paling bawah, bagian bawah berbentuk sendok, bagian depan berbentuk - M.

S. inermis memiliki persebaran yang luas yaitu Samudra Hindia, Laut Merah, Arabia bagian Selatan, timur dan barat pantai India, Pulau Andaman, Ceylon, Burma, Malaysia, Indonesia dan Vietnam. Sementara itu daerah persebaran di Indonesia berada di Perairan sekitar Sabang, Laut Jawa, dan Selat Makasar. Supongpan (1988), menyatakan bahwa S. inermis dapat ditemukan pada kisaran kedalaman 10-20 meter.

Penelitian ini bertujuan untuk mengkaji hubungan panjang-berat dan faktor kondisi sotong $(S$. inermis) untuk keperluan praktis di bidang perikanan, mengetahui karakteristik morfometrik dan sifat pertumbuhan alometrik sebagai data dasar morfologi atau biologi pada sotong (S. inermis). Penelitian ini telah dilaksanakan pada bulan Desember 2012 - Februari 2013 di PPI Tambaklorok.

Parameter yang akan dibandingkan dapat dikuantifikasi/diukur dengan akurat, maka kaitan antar dua parameter pertumbuhan pada bagian tubuh manapun dapat ditaksir melalui persamaan regresi non-linier, yaitu :

$$
\mathrm{Y}=\mathrm{aX}
$$

Linierisasi persamaan tersebut adalah: $\log _{10} \mathrm{Y}=\log _{10} \mathrm{a}+\mathrm{b} \log _{10} \mathrm{X}$

Secara grafis $\mathrm{x}$ dan $\mathrm{Y}$ adalah variabel bebas dan terikat, sedangkan $\mathrm{A}$ dan $\mathrm{b}$ masing-masing merupakan intercept dan slope dari grafik regresi yang dihasilkan persamaan (2). Bentuk angka satuan (unity) bagi $\mathrm{b}$ mendeskripsikan pertumbuhan yang isometris atau relatif identik bagi dua variabel yang diperbandingkan, dan dinyatakan sebagai angka teoritis $\beta$. Bila $b>\beta$ berarti $Y$ tumbuh relatif lebih cepat daripada $x$, disebut alometri positif. Tetapi bila $b<\beta$ berarti $\mathrm{Y}$ tumbuh relatif lebih lambat daripada $\mathrm{x}$ atau disebut alometri negatif, dan bila $b=\beta$ berarti kedua variabel $Y$ dan $x$ tumbuh pada kecepatan yang relatif seimbang atau isometrik (Afiati, 2005). Kriteria alometri dan isometri yang sedikit berbeda berlaku bila unit pengukuran variabel pertumbuhan yang dibandingkan tidak sama.

Uji statistik sederhana berikut ini digunakan untuk mengetahui penyimpangan dari pola pertumbuhan isometrik atas variabel-variabel yang diperbandingkan (Afiati, 2005):

$$
t_{\text {obs }}(n-1) d f=\frac{(b-\beta)}{S_{\text {error dari } b}}
$$




\section{Materi dan Metode Penelitian}

\section{A. Materi Penelitian}

Peralatan yang digunakan dalam penelitian ini adalah jangka sorong digunakan untuk mengukur panjang mantel sotong (S. inermis) dengan satuan $\mathrm{mm}$ dan memiliki ketelitian $0,01 \mathrm{~mm}$. Timbangan elektrik digunakan untuk menimbang berat sotong (S. inermis) dengan ketelitian $0,01 \mathrm{mg}$. Selain itu juga ada mikroskop, penggaris, sectio kit, parafin, kamera, oven, desikator, cawan petri. Bahan yang digunakan adalah sampel sotong (S. inermis) yang diperoleh dari PPI Tambaklorok. Serta buku identifikasi Cephalopoda dari FAO vol.2 tahun 1998, vol. 1 tahun 2002, dan vol. 1 tahun 2005 yang digunakan untuk mengidentifikasi jenis dari sotong (S. inermis). Laptop untuk mengolah data panjang total ( $\mathrm{mm}$ ) dan data berat (gram), perangkat lunak (software) yang digunakan untuk mengolah data tersebut adalah microsoft office exel 2003, microsoft office excel 2007 serta SPSS 16.

B. Metode Penelitian

Metode penelitian yang digunakan dalam penelitian ini adalah metode deskriptif yang dalam pelaksanaannya dilakukan melalui teknik survei yaitu melakukan kegiatan pengamatan secara langsung di lapangan (Suryana, 2010). Pengambilan sampel dilakukan dengan metode systematic random sampling. Sistematik maksudnya sampel diambil pada tempat yang sama, dalam selang waktu yang sama. Pengambilan sampel dilakukan sebayak enam kali dimana setiap sampling diambil 10\% dari sampel yang ada sehingga dapat mewakili populasi. Alasan pemilihan sotong maupun PPI Tambaklorok ini adalah yaitu antara lain sampel sotong selalu ada sepanjang waktu penelitian, cukup mudah didapatkan dan sampel $S$. inermis ini lebih banyak secara kuantitas daripada jenis sotong lainnya. Berdasarkan survei di beberapa TPI di Demak, Jepara, dan Kendal sotong $S$. inermis tidak selalu tersedia dan ada TPI yang tidak beroperasi karena cuaca yang extrim. Adapun kekurangan dari sampel ini yaitu tubuhnya yang lunak sehingga mengurangi tingkat ketelitian/keakuratan saat pengukuran. Selanjutnya sampel sotong (S. inermis) dilakukan pengukuran variabel yaitu panjang mantel, panjang kepala, panjang mata, tinggi mata, panjang lengan, panjang tentakel, panjang cangkang, lebar cangkang, lebar badan, panjang sirip, lebar sirip dan berat basah (Gambar 1).
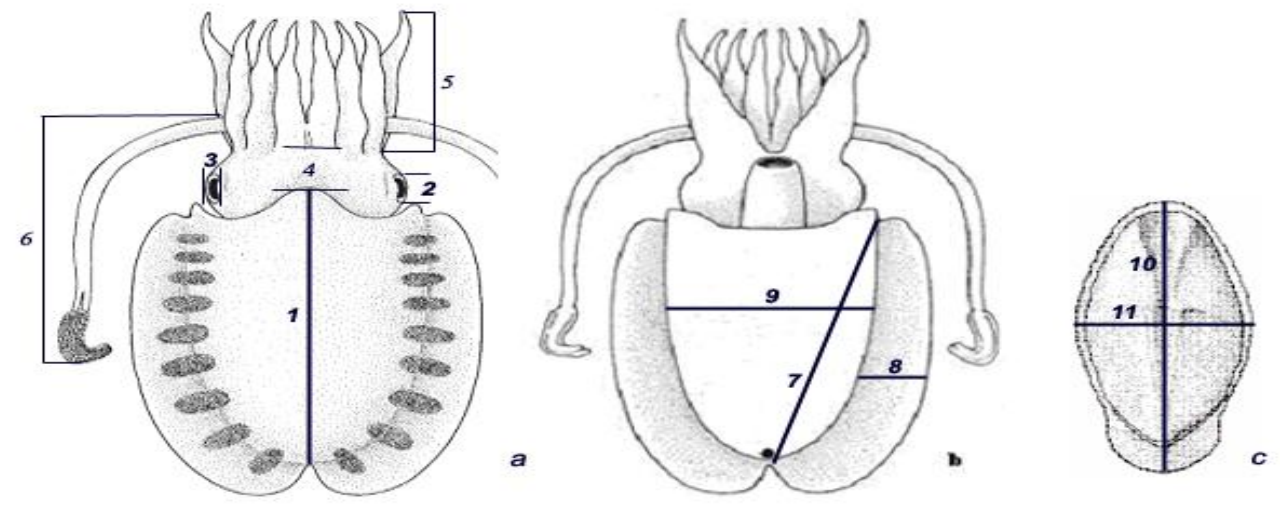

1. Mantle Length (ML)/ Panjang Mantel

2. Eye Length (EL)/ Panjang Mata

3. Eye Height $(\mathrm{EH}) /$ Tinggi Mata

4. Head Length $(\mathrm{HL}) /$ Panjang Kepala

5. Arm Length (AL)/ Panjang Lengan

6. Tentacle Length (TL)/ Panjang Tentakel
7. Fin Length (FL)/ Panjang Sirip

8. $\quad$ Fin Width (FW)/ Lebar Sirip

9. BodyWidth (BW)/ Lebar Badan

10. Sepion Length (SL)

11. Sepion Width (SW)

12. Berat Basah (Ww, Wet weight)

Keterangan: a. tampak dorsal, b. ventral, c. sepion

Gambar 1. Dimensi pengukuran morfometrik S. inermis dan sepion yang dilakukan Sumber : Nateewathana, 2008

Hubungan panjang berat ditentukan dengan persamaan:

$$
\mathrm{W}=\mathrm{aL}^{\mathrm{b}} \text {..... }
$$

dimana, $\mathrm{W}=$ berat (gram), $\mathrm{L}=$ panjang mantel $(\mathrm{mm})$, $\mathrm{a}$ dan $\mathrm{b}=$ konstanta. Bila nilai $\mathrm{b} \neq 3$ maka faktor kondisi dihitung dengan rumus: $\mathrm{Kn}=\mathrm{W} / \mathrm{aL}^{\mathrm{b}}$, dimana $\mathrm{W}=$ berat rata - rata sesungguhnya, $\mathrm{L}=$ panjang mantel $(\mathrm{mm})$, a dan $\mathrm{b}=$ konstanta.

Nilai faktor kondisi akan lebih penting dan lebih bermakna jika dibandingkan antar ukuran atau antar lokasi, karena jika terpaku hanya kepada satu nilai FK tidak banyak artinya, atau bahkan tidak ada (Saputra, 2009). 


\section{Hasil dan Pembahasan}

\section{Struktur Populasi}

Sotong (S. inermis) yang didapatkan selama penelitian, memiliki kisaran panjang mantel antara 11,10 - 96,70 mm yaitu sebanyak 316 individu. Frekuensi distribusi ukuran pada $S$. inermis berdasarkan panjang mantel $(\mathrm{mm})$ tersaji pada Tabel 1.

Tabel 1. Sebaran ukuran pada S. inermis selama penelitian yang didaratkan di PPI Tambaklorok $\mathrm{n}=316$

\begin{tabular}{cc}
\hline Kisaran Panjang Mantel $(\mathrm{mm})^{*}$ & frekuensi (individu) \\
\hline $11-20$ & 57 \\
$20-28$ & 104 \\
$28-37$ & 45 \\
$37-45$ & 34 \\
$45-54$ & 33 \\
$54-62$ & 16 \\
$62-71$ & 13 \\
$71-80$ & 6 \\
$80-88$ & 4 \\
$88-97$ & 3 \\
$97-105$ & 1
\end{tabular}

* Angka pembulatan

Frekuensi S. inermis berdasarkan ukuran panjang mantel yang didaratkan di PPI Tambaklorok selama penelitian tersaji pada Gambar 2.

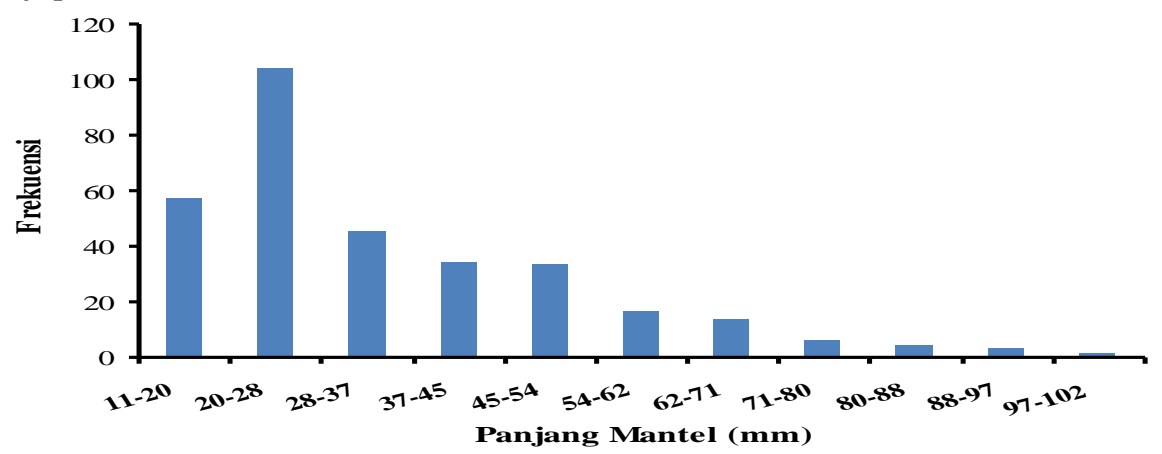

Gambar 2. Distribusi frekuensi S. inermis berdasarkan ukuran panjang mantel

\section{Analisis Panjang Berat dan Faktor Kondisi}

Total sampel $S$. inermis yang didapatkan sebanyak 316 individu memiliki kisaran panjang mantel 11,10 mm sampai 96,70 mm. Dari hasil analisa panjang berat didapatkan angka a $=0,00129, b=2,4978$. Berdasarkan angka "b" maka sifat pertumbuhan $S$. inermis berdasarkan panjang dan berat basah adalah alometrik negatif yaitu pertumbuhan panjangnya lebih cepat dari pertumbuhan berat. Sehingga hubungan panjang berat sotong $S$. inermis mengikuti persamaan $\mathrm{W}=0,00129 \mathrm{~L}^{2,4978}$. Hubungan panjang-berat $S$. inermis selama penelitian dapat dilihat pada Gambar 3 di bawah ini.

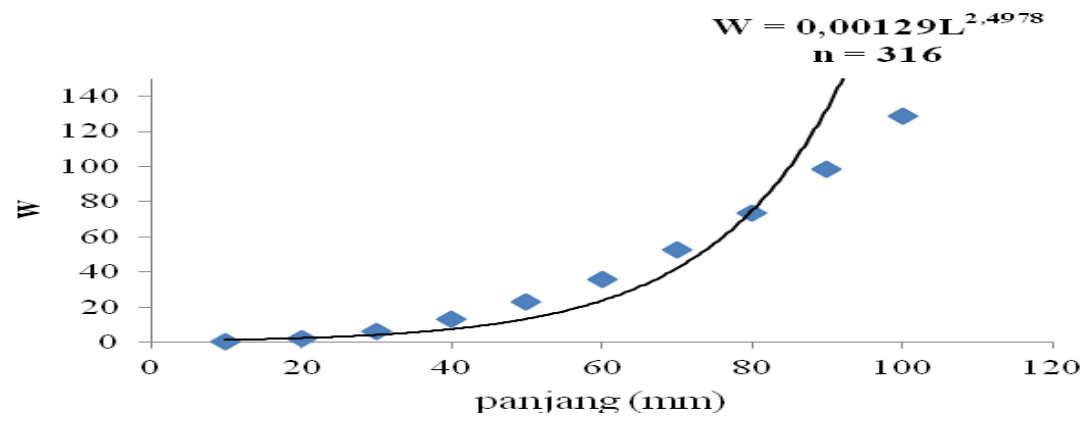

Gambar 3. Korelasi Panjang Berat S. inermis selama Penelitian.

Keterangan: $\diamond=$ panjang berat gabungan jantan dan betina,

$\longrightarrow=$ ekponensial 
Hasil perhitungan Faktor Kondisi S. inermis tersaji pada Tabel 2.

Tabel 2. Angka Faktor Kondisi (Kn) S. inermis yang didaratkan di PPI Tambaklorok bulan Desember 2012 Februari 2013

\begin{tabular}{ccccc}
\hline $\begin{array}{l}\text { Jumlah } \\
\text { sampel }\end{array}$ & $\begin{array}{c}\text { panjang } \\
\text { rata-rata }(\mathrm{mm}) \pm \mathrm{SD}\end{array}$ & $\begin{array}{c}\text { berat rata-rata } \\
\mathrm{w}(\mathrm{gram}) \pm \mathrm{SD}\end{array}$ & $\begin{array}{c}\text { Rata-rata } \\
\mathrm{W}=\mathrm{aL}^{\mathrm{b}}\end{array}$ & $\mathrm{Kn}=\mathrm{w} / \mathrm{W}$ \\
\hline 316 & $34,22 \pm 17,27$ & $13.28 \pm 16.79$ & 13,311 & 1,00 \\
\hline \multicolumn{5}{r}{ Dari hasil diatas menunjukkan bahwa nilai faktor kondisi berkisar antara 1 - 3, yang berarti S. inermis } \\
memiliki badan yang kurang pipih. \\
Pertumbuhan Alometrik
\end{tabular}

Dari lokasi penelitian diperoleh ukuran panjang mantel rata-rata $S$. inermis adalah $34,22 \pm 17,27 \mathrm{~mm}$ dengan kisaran 11,10 - 96,7 mm. Dimensi pengukuran morfometri yang dilakukan terhadap S. inermis menghasilkan tipe pertumbuhan isometrik, alometri negatif, dan alometri positif sebagaimana tersaji pada Tabel 3.

Tabel 3. Pertumbuhan alometrik beberapa variabel morfometrik $S$. inermis yang didaratkan di PPI Tambaklorok Semarang, $n=316$

\begin{tabular}{|c|c|c|c|c|c|c|c|c|c|}
\hline \multicolumn{2}{|c|}{ Variabel } & \multirow[b]{2}{*}{$\mathrm{a}$} & \multirow{2}{*}{$\mathrm{b}$} & \multirow{2}{*}{$\beta$} & \multirow{2}{*}{$\mathrm{S}_{\mathrm{eb}}$} & \multirow{2}{*}{$\mathrm{t}_{\mathrm{obs}}$} & \multirow{2}{*}{ Alometri } & \multirow{2}{*}{$\mathrm{r}$} & \multirow{2}{*}{$\mathrm{R}^{2}$} \\
\hline Terikat & Bebas & & & & & & & & \\
\hline \multirow[t]{11}{*}{ HL } & $\mathrm{EH}$ & 0.623 & 0.755 & 1 & 0.030 & $-8.1667 *$ & - & 0.819 & 0.67 \\
\hline & $\mathrm{AL}$ & 0.460 & 0.504 & 1 & 0.019 & $-26.1053 *$ & - & 0.826 & 0.68 \\
\hline & FW & 0.694 & 0.623 & 1 & 0.024 & $-15.7083 *$ & - & 0.825 & 0.68 \\
\hline & $\mathrm{BW}$ & 0.085 & 0.721 & 1 & 0.026 & $-10.7308 *$ & - & 0.843 & 0.71 \\
\hline & EL & 0.437 & 0.861 & 1 & 0.029 & $-4.7931 *$ & - & 0.860 & 0.74 \\
\hline & $\overline{T L}$ & -0.425 & 0.753 & 1 & 0.027 & $-9.1481 *$ & - & 0.846 & 0.72 \\
\hline & FL & 0.106 & 0.689 & 1 & 0.017 & $-18.2941 *$ & - & 0.913 & 0.83 \\
\hline & ML & 0.083 & 0.683 & 1 & 0.018 & $-17.6111 *$ & - & 0.906 & 0.82 \\
\hline & SL & 0.147 & 0.658 & 1 & 0.018 & $-19.0000 *$ & - & 0.900 & 0.81 \\
\hline & SW & 0.431 & 0.645 & 1 & 0.019 & $-18.6842 *$ & - & 0.884 & 0.78 \\
\hline & Ww & 0.606 & 0.269 & 0.333 & 0.007 & $-9.1905 *$ & - & 0.906 & 0.82 \\
\hline \multirow[t]{10}{*}{ EH } & $\mathrm{AL}$ & -0.025 & 0.518 & 1 & 0.023 & $-20.9565 *$ & - & 0.781 & 0.61 \\
\hline & FW & 0.196 & 0.670 & 1 & 0.027 & $-12.2222 *$ & - & 0.819 & 0.67 \\
\hline & BW & -0.452 & 0.770 & 1 & 0.029 & $-7.9310 *$ & - & 0.830 & 0.69 \\
\hline & EL & -0.145 & 1.010 & 1 & 0.023 & $0.4348 \mathrm{~ns}$ & isometrik & 0.929 & 0.86 \\
\hline & TL & -1.077 & 0.844 & 1 & 0.026 & $-6.0000 *$ & - & 0.874 & 0.76 \\
\hline & FL & -0.428 & 0.735 & 1 & 0.020 & $-13.2500 *$ & - & 0.897 & 0.81 \\
\hline & ML & -0.471 & 0.714 & 1 & 0.020 & $-14.3000 *$ & - & 0.906 & 0.82 \\
\hline & SL & -0.407 & 0.718 & 1 & 0.019 & $-14.8421 *$ & - & 0.905 & 0.82 \\
\hline & SW & -0.102 & 0.708 & 1 & 0.020 & $-14.6000 *$ & - & 0.894 & 0.80 \\
\hline & Ww & 0.099 & 0.291 & 0.333 & 0.008 & $-5.2917 *$ & - & 0.902 & 0.81 \\
\hline \multirow[t]{9}{*}{$\mathrm{AL}$} & FW & 0.654 & 0.943 & 1 & 0.045 & $-1.2667 \mathrm{~ns}$ & isometrik & 0.763 & 0.58 \\
\hline & BW & -0.328 & 1.134 & 1 & 0.046 & $2.9130 *$ & + & 0.810 & 0.66 \\
\hline & EL & 0.250 & 1.323 & 1 & 0.055 & $5.8727 *$ & + & 0.807 & 0.65 \\
\hline & TL & -1.119 & 1.179 & 1 & 0.048 & $3.7292 *$ & + & 0.809 & 0.65 \\
\hline & FL & -0.250 & 1.053 & 1 & 0.037 & $1.4324 \mathrm{~ns}$ & isometrik & 0.852 & 0.73 \\
\hline & ML & -0.300 & 1.053 & 1 & 0.036 & $1.4722 *$ & isometrik & 0.853 & 0.73 \\
\hline & SL & -0.192 & 1.009 & 1 & 0.036 & $0.2500 \mathrm{~ns}$ & isometrik & 0.843 & 0.71 \\
\hline & SW & 0.263 & 0.970 & 1 & 0.039 & $-0.7692 \mathrm{~ns}$ & isometrik & 0.811 & 0.66 \\
\hline & Ww & 0.506 & 0.416 & 0.333 & 0.014 & $5.9048 *$ & + & 0.855 & 0.73 \\
\hline \multirow[t]{8}{*}{ FW } & BW & -0.654 & 0.927 & 1 & 0.037 & $-1.9730 *$ & - & 0.818 & 0.67 \\
\hline & EL & -0.207 & 1.114 & 1 & 0.041 & $2.7805 *$ & + & 0.839 & 0.70 \\
\hline & $\mathrm{TL}$ & -1.361 & 0.994 & 1 & 0.036 & $-0.1667 \mathrm{~ns}$ & isometrik & 0.842 & 0.71 \\
\hline & FL & -0.619 & 0.880 & 1 & 0.027 & $-4.4444 *$ & - & 0.880 & 0.77 \\
\hline & ML & -0.658 & 0.879 & 1 & 0.027 & $-4.482 *$ & - & 0.880 & 0.77 \\
\hline & SL & -0.574 & 0.846 & 1 & 0.027 & $-5.704 *$ & - & 0.874 & 0.76 \\
\hline & SW & -0.199 & 0.820 & 1 & 0.029 & $-6.207 *$ & - & 0.848 & 0.72 \\
\hline & Ww & 0.017 & 0.346 & 0.333 & 0.011 & $1.156 \mathrm{~ns}$ & isometrik & 0.878 & 0.77 \\
\hline
\end{tabular}


Lanjutan Tabel 3. Pertumbuhan alometrik beberapa variabel morfometrik $S$. inermis yang didaratkan di PPI Tambaklorok Semarang, $\mathrm{n}=316$

\begin{tabular}{|c|c|c|c|c|c|c|c|c|c|}
\hline \multicolumn{2}{|c|}{ Variabel } & \multirow{2}{*}{$\mathrm{a}$} & \multirow{2}{*}{$\mathrm{b}$} & \multirow{2}{*}{$\beta$} & \multirow{2}{*}{$\mathrm{S}_{\mathrm{eb}}$} & \multirow{2}{*}{$\mathrm{t}_{\mathrm{obs}}$} & \multirow{2}{*}{ Alometri } & \multirow{2}{*}{$\mathrm{r}$} & \multirow{2}{*}{$\mathrm{R}^{2}$} \\
\hline Terikat & Bebas & & & & & & & & \\
\hline \multirow[t]{7}{*}{$\mathrm{BW}$} & EL & 0.655 & 0.977 & 1 & 0.036 & $-0.639 \mathrm{~ns}$ & isometrik & 0.834 & 0.70 \\
\hline & $\mathrm{TL}$ & -0.393 & 0.890 & 1 & 0.031 & $-3.548 *$ & - & 0.854 & 0.73 \\
\hline & FL & 0.253 & 0.801 & 1 & 0.021 & $-9.476 *$ & - & 0.907 & 0.82 \\
\hline & ML & 0.208 & 0.806 & 1 & 0.020 & $-9.700 *$ & - & 0.914 & 0.84 \\
\hline & SL & 0.281 & 0.778 & 1 & 0.020 & $-11.100 *$ & - & 0.910 & 0.83 \\
\hline & SW & 0.626 & 0.755 & 1 & 0.023 & $-10.652 *$ & - & 0.884 & 0.78 \\
\hline & Ww & 0.828 & 0.316 & 0.333 & 0.008 & $-2.167 *$ & - & 0.910 & 0.83 \\
\hline \multirow[t]{6}{*}{ EL } & $\mathrm{TL}$ & -0.806 & 0.778 & 1 & 0.024 & $-9.250 *$ & - & 0.876 & 0.77 \\
\hline & FL & -0.223 & 0.688 & 1 & 0.017 & $-18.353 *$ & - & 0.913 & 0.83 \\
\hline & ML & -0.260 & 0.691 & 1 & 0.017 & $-18.177 *$ & - & 0.919 & 0.85 \\
\hline & SL & -0.196 & 0.667 & 1 & 0.017 & $-19.588 *$ & - & 0.914 & 0.84 \\
\hline & SW & 0.087 & 0.659 & 1 & 0.018 & $-18.944 *$ & - & 0.904 & 0.82 \\
\hline & Ww & 0.275 & 0.270 & 0.333 & 0.007 & $-9.048 *$ & - & 0.909 & 0.83 \\
\hline \multirow[t]{5}{*}{ TL } & FL & 0.891 & 0.786 & 1 & 0.018 & $-11.889 *$ & - & 0.927 & 0.86 \\
\hline & ML & 0.849 & 0.790 & 1 & 0.017 & $-12.352 *$ & - & 0.933 & 0.87 \\
\hline & SL & 0.918 & 0.764 & 1 & 0.017 & $-13.882 *$ & - & 0.930 & 0.87 \\
\hline & SW & 1.243 & 0.754 & 1 & 0.018 & $-13.667 *$ & - & 0.920 & 0.85 \\
\hline & Ww & 1.460 & 0.308 & 0.333 & 0.007 & $-3.619 *$ & - & 0.923 & 0.85 \\
\hline \multirow[t]{5}{*}{ FL } & ML & -0.029 & 0.988 & 1 & 0.008 & $-1.500 \mathrm{~ns}$ & isometrik & 0.990 & 0.98 \\
\hline & SL & 0.058 & 0.956 & 1 & 0.009 & $-4.889 *$ & - & 0.988 & 0.98 \\
\hline & SW & 0.472 & 0.936 & 1 & 0.014 & $-4.571 *$ & - & 0.968 & 0.94 \\
\hline & BW & -0.004 & 1.027 & 1 & 0.027 & $1.000 \mathrm{~ns}$ & isometrik & 0.907 & 0.82 \\
\hline & Ww & 0.733 & 0.387 & 0.333 & 0.004 & $13.417 *$ & + & 0.982 & 0.96 \\
\hline \multirow[t]{2}{*}{ ML } & SL & 0.097 & 0.961 & 1 & 0.007 & $-5.571 *$ & - & 0.992 & 0.98 \\
\hline & SW & 0.515 & 0.940 & 1 & 0.013 & $-4.615 *$ & - & 0.970 & 0.94 \\
\hline \multirow[t]{2}{*}{ SL } & SW & 0.440 & 0.973 & 1 & 0.013 & $-2.077 *$ & - & 0.974 & 0.95 \\
\hline & BW & -0.052 & 1.065 & 1 & 0.027 & $2.407 *$ & + & 0.910 & 0.83 \\
\hline SL & Ww & 0.714 & 0.400 & 0.333 & 0.004 & $16.667 *$ & + & 0.985 & 0.97 \\
\hline \multirow[t]{2}{*}{ SW } & BW & -0.422 & 1.036 & 1 & 0.031 & $1.161 \mathrm{~ns}$ & isometrik & 0.884 & 0.78 \\
\hline & Ww & 0.321 & 0.390 & 0.333 & 0.007 & $8.095 *$ & + & 0.958 & 0.92 \\
\hline $\mathrm{Ww}$ & ML & 0.0013 & 2.498 & 3 & 0.250 & $-2.008 *$ & - & 0.985 & 0.97 \\
\hline
\end{tabular}

Keterangan:

$* \quad=$ Berbeda sangat nyata pada $\mathrm{p}<0.05\left(\mathrm{n}=\infty, \mathrm{t}_{0.05}=1.967\right)$

ns $\quad=$ Tidak berbeda nyata pada $\mathrm{p}<0.05$

- $\quad=$ Alometri negatif

$+\quad=$ Alometri positif

Notasi variabel: lihat Gambar 1.

Data produksi Cephalopoda secara umum di Kota Semarang selama 13 tahun terakhir yakni dari tahun 1999-2011 tersaji pada Gambar 4.

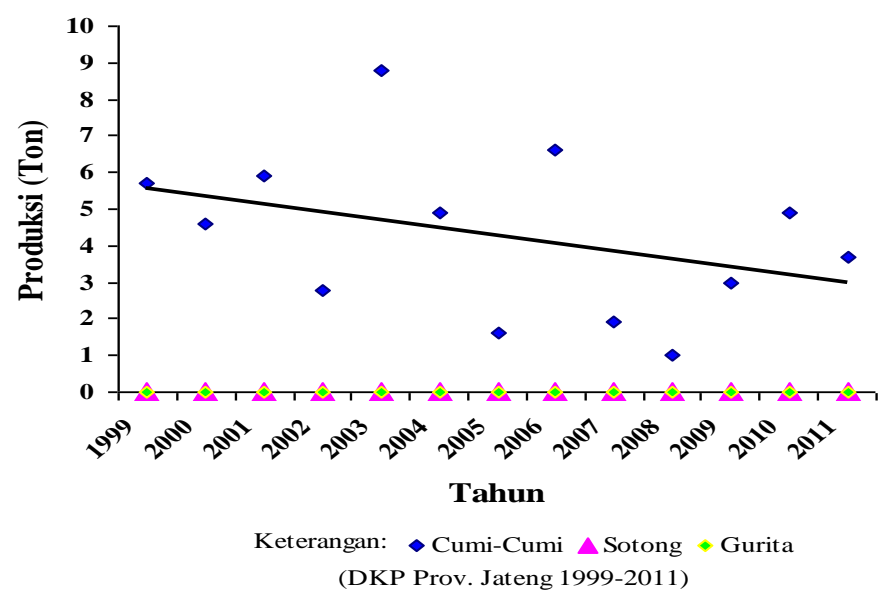

Gambar 4. Produksi Cephalopoda Tahun 1999-2011 di Kota Semarang Sumber: Statistik Propinsi Jawa Tengah Tahun 1999-2011 
Pembahasan

PPI Tambaklorok terletak di Kelurahan Tanjung Mas, Kecamatan Semarang Utara yang merupakan pusat kegiatan perikanan tangkap dan sekaligus merupakan komunitas nelayan terbesar di Kota Semarang. Luas areal keseluruhan sekitar 38 Ha.

Dari jumlah sampel yang didapatkan sebanyak 316 spesimen dengan panjang mantel berkisar antara 11.10-96.70 mm (rata-rata 34,22 $\pm 17,27 \mathrm{~mm}$ ) dan berat berkisar antara 0.76-83.41 gram. Perhitungan hubungan panjang berat selama penelitian menunjukkan bahwa $S$. inermis memiliki angka "b" $<3$, dengan pertumbuhannya mengikuti persamaan $\mathrm{W}=0,00129 \mathrm{~L}^{2,4979}$, sehingga dapat dikatakan bahwa pertumbuhannya bersifat alometrik negatif yaitu pertambahan panjang lebih cepat dari pertambahan berat (Effendie, 2002).

Hasil tersebut serupa dengan penelitian-penelitian yang dilakukan terhadap spesies yang sama diberbagai tempat seperti tersaji pada Tabel 4

Tabel 4. Persamaan panjang berat $S$. inermis berdasarkan penelitian yang telah dilakukan.

\begin{tabular}{|c|c|c|c|c|}
\hline No & Spesies & Persamaan & Lokasi & Pustaka \\
\hline 1. & S. inermis & $\delta: W=0,01096 \mathrm{~L}^{1,9320}$ & Mandapam, India & Unnithan (1974) \\
\hline 2. & S. inermis & $\mathrm{W}=0,003849 \mathrm{~L} 2,2787$ & Kakinada, India & Appannasastry (1989) \\
\hline 3. & S. inermis & $\delta: W=0,002168 \mathrm{~L} 2,1532$ & Perairan Tuticorin, India & Neethiselvan (1999) \\
\hline
\end{tabular}

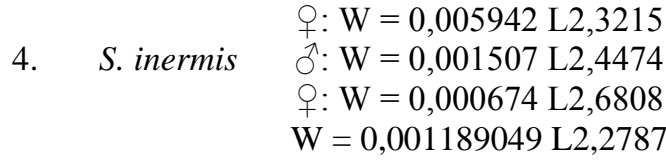

5. S. inermis $\quad \mathrm{W}=0,00129 \mathrm{~L} 2,4978$

Perairan Mumbai, India

Sundaram \& Zafar (2011)

PPI Tambaklorok, Semarang

Penelitian ini

Hasil panjang berat tersebut serupa dengan penelitian yang dilakukan oleh Unnithan (1974) di Mandapam, Appannasastry (1989) di Kakinada, India menunjukkan bahwa S. inermis memiliki sifat pertumbuhan yang alometrik negatif. Sementara itu Sundaram dan Khan (2011) yang melakukan studi di perairan Mumbai India, mendapatkan bahwa pada $S$. inermis betina menunjukkan sifat pertumbuhan yang isometrik, akan tetapi pada jantan dan gabungan keduanya menunjukkan sifat yang alometrik negatif, dimana pertambahan panjang mantelnya lebih cepat daripada berat dan hubungan tersebut memiliki keeratan yang baik sebesar $85,9 \%$.

Secara umum, nilai "b" dipengaruhi oleh faktor dalam dan luar. Faktor dalam seperti kondisi fisiologis, genetik, jenis kelamin, umur, parasit atau penyakit. Faktor luar yaitu berasal dari lingkungan seperti suhu, pH, salinitas dan letak geografis (Jenning et al., 2001) dan juga kondisi biologis seperti perkembangan gonad dan ketersediaan makanan yang ada di daerah tersebut (Froese, 2006).

Sementara itu nilai faktor kondisi $(\mathrm{Kn})$ S. inermis yang didaratkan di PPI Tambaklorok yaitu 1,00 sehingga memiliki bentuk yang kurang pipih. Effendie (2002), menyatakan bahwa kisaran harga Kn antara 2 - 4 berarti gemuk, sedangkan kisaran 1 - 2 badan kurus. Menurut Le Cren dalam Merta (1993), angka faktor kondisi sebagai indikasi berbagai sifat-sifat biologi dari ikan, seperti gemuk, kesesuaian dengan lingkungannya atau perkembangan gonadnya. Variasi pasokan pakan yang terjadi antar musim dapat mengubah faktor kondisi musiman (Offem et al., 2007). Faktor kondisi ini mencerminkan karakteristik morfologi tubuh, kandungan lipid dan tingkat pertumbuhan (Bister et al., 2000; Rypel \& Richter, 2008; Froese, 2006).

Tampak dari Tabel 3 bahwa panjang kepala (HL) bersifat alometri negatif terhadap panjang mata (EL), tinggi mata $(\mathrm{EH})$, panjang lengan (AL), panjang tentakel (TL), panjang mantel (ML), panjang sirip (FL), lebar sirip (FW), panjang sepion (SL), lebar sepion (SW), lebar badan (BW) dan berat basah (Ww). Dari keadaan tersebut dapat diterangkan bahwa kecepatan tumbuh kepala lebih lambat daripada variabel yang diperbandingkan. Serupa dengan itu, panjang mata bersifat alometri negatif terhadap variabel-variabel yang diperbandingkan (EL-ML, TL, FL, SL, SW, Ww). Mata pada sotong berkembang dengan luar biasa bahkan pada sebagian besar Moluska karena alat penglihatan ini berperan penting dalam kehidupannya. Cumi-cumi dan sotong mempunyai pergerakan atau mobilitas yang sangat tinggi karena sistem penglihatannya terkoordinasi sangat baik dengan otot lengan dan tentakel (FAO, 2005). Panjang mantel bersifat alometri negatif terhadap panjang cangkang dan lebar cangkang.

Panjang mantel bersifat alometri negatif terhadap panjang cangkang dan lebar cangkang. Sementara itu, lengan tumbuh lebih cepat daripada panjang tentakel, panjang mata, lebar badan dan berat basah. Dilihat dari nilai koefisien korelasi (r) yang berkisar antara 78,1\% - 82,6\% panjang lengan merupakan variabel yang sulit diukur karena elastis. Secara garis besar lengan dan tentakel mempunyai jaringan otot yang secara fungsional berperan dalam pergerakan. Otot tersebut terletak membujur pada sisi lengan. Lengan mampu menghasilkan suatu cakupan pergerakan luar biasa seperti pemanjangan, pemendekan, dan elastis dalam keadaan apapun. Elastisitas dari lengan tersebut penting dalam sotong mengatasi dan menundukkan mangsa selama proses pencernaan (Kier, 1988). 
Variabel yang isometrik atau tumbuh pada kecepatan seimbang terjadi pada panjang lengan terhadap panjang mantel, panjang sirip, lebar sirip, panjang cangkang, dan lebar cangkang. Diduga pertumbuhan tersebut terkait dari fungsi masing-masing anggota tubuh dalam menangkap mangsa, beruaya, dan untuk menjaga keseimbangan tubuhnya saat berenang. Hal tersebut sesuai dengan Richard (1972) dalam Almonacid (2009) bahwa karakteristik pada cuttlefish ditandai oleh adanya internal shell sebagai rangka dengan berbahan zat kapur (calsium carbonat) yang memiliki peranan penting dalam mengendalikan tubuh saat pengapungan maupun berenang.

Variabel tinggi mata bersifat alometri negatif terhadap panjang lengan, panjang tentakel, panjang mantel, panjang sirip, lebar sirip, panjang cangkang, lebar cangkang, lebar badan dan berat basah. Hal tersebut serupa dengan panjang sirip, lebar sirip yang bersifat alometri negatif dimana pertumbuhannya lebih lambat terhadap variabel-variabel yang diperbandingkan (FL-CL, CW) dan (FW-FL, ML, CL, CW, BW). Panjang tentakel bersifat alometri negatif terhadap panjang sirip, panjang mantel, panjang cangkang, lebar cangkang, dan berat basah. Hasil tersebut dapat diasumsikan bahwa tentakel tunbuh lebih lambat dari variabel yang diperbandingkan, akan tetapi saat variabel-variabel lain tumbuh mencapai akhir batasnya tentakel masih dapat tumbuh memanjang dengan cepat.

Pertumbuhan tentakel penting bagi sotong karena terkait dengan fungsinya dalam menangkap mangsa. Sotong menangkap dan menundukkan mangsa dengan dua tentakel dan delapan lengan yang berotot. Salah satu tentakel digunakan digunakan untuk menangkap mangsa dengan pemanjangan yang cepat, ketika empat pasang lengan yang lainnya menerima mangsa dan mengorientasikannya dengan membengkokkan dan mengurangi pergerakan mangsa menggunakan batil penghisap untuk selanjutnya dimasukkan kedalam mulut. Tentakel sotong dapat mengalami perpanjangan dengan kecepatan luar biasa selama menangkap mangsa, dan dapat menjangkau mangsa dengan kecepatan sedikitnya 15 m/s (Kier, 1982; Messenger, 1968, 1977 dalam Kier, 1988).

Lebar badan memiliki kecepatan tumbuh lebih lambat daripada panjang tentakel, panjang sirip, panjang mantel, panjang cangkang, lebar cangkang, dan berat basah. Sementara itu panjang sirip mempunyai kecepatan tumbuh yang seimbang terhadap panjang mantel dan lebar badan. Panjang cangkang mempunyai kecepatan tumbuh yang relaif lebih lambat daripada lebar cangkang.

Asumsi awal pada sotong atau Cephalopoda umumnya ini adalah karena sotong merupakan hewan predator sehingga mata merupakan salah satu organ yang mempunyai peran vital dalam pertumbuhannya. Oleh karena itu mata diasumsikan mempunyai kecepatan tumbuh yang lebih cepat daripada variabel yang diukur atau organ tubuh lainnya. Akan tetapi, dari hasil pengukuran morfometri didapatkan bahwa lengan merupakan organ tubuh yang memiliki kecepatan tumbuh lebih cepat atau seimbang dari organ yang lainnya. Hal itu dipengaruhi oleh peran lengan yang sangat penting dalam menjalani masa pertumbuhannya dalam menangkap buruannya.

Berdasarkan data statistik perkembangan produksi Cephalopoda di Kota Semarang, dari tahun 19992011, produksi cumi-cumi mengalami perubahan yang fluktuatif dari tiap tahun dengan kenaikan dan penurunan yang tidak terlalu signifikan. Secara keseluruhan produksi cumi-cumi di Kota Semarang dapat dikatakan mengalami penurunan produksi. Tahun 2003 merupakan produksi cumi-cumi yang tertinggi yaitu mencapai 8,8 ton, tahun 2008 merupakan produksi terendah mencapai 1,0 ton. Akan tetapi setelah tahun 2008 produksi cumi-cumi sudah mulai meningkat dengan produksi mencapai 3,0 ton tahun 2009 dan 4,87 ton tahun 2010. Tahun 2011 menurun kembali menjadi 3,7 ton. Produksi sotong dan gurita di Kota Semarang dari tahun 1999-2011 yaitu 0 ton, hal tersebut bukan berarti tidak ada data yang tersedia akan tetapi produksi sotong dan gurita tidak mencapai satuan terkecil statistik yang ada (Ton).

\section{Kesimpulan}

Kesimpulan yang diperoleh dari penelitian yang telah dilakukan adalah:

1. Analisis panjang berat dan faktor kondisi adalah sebagai berikut:

a. Angka "b" S. inermis selama penelitian 2,4978 (angka b < 3) sehingga pertumbuhan bersifat allometrik negatif yakni pertambahan panjang lebih cepat dari pertambahan berat;

b. Angka faktor kondisi (Kn) dari S. inermis selama penelitian 1,00 yang berarti kurang dari 2, sehingga bentuk sotong tersebut kurang pipih;

2. Dari pengukuran morfometri sampel yang dilakukan sebagian besar didominasi oleh kisaran ukuran panjang mantel 11-30 mm dari ukuran 11-97 $\mathrm{mm}$, hal tersebut menunjukkan bahwa populasi sotong yang tertangkap merupakan juvenile dan lengan memiliki pertumbuhan yang lebih cepat daripada pertumbuhan mata, kepala, dan tentakel. Hal tersebut menunjukkan pentingnya fungsi lengan pada sotong.

\section{Ucapan Terima Kasih}

Ucapan terima kasih penulis tujukan kepada Prof. Norma Afiati, M.Sc, Ph.D dan Dr. Ir. Haeruddin, M.Si atas pendanaan, bimbingan dan arahan dalam penyusunan karya ilmiah ini. 


\section{Daftar Pustaka}

Affandi, R, S.S. Djadja, M.F. Rahardjo, Sulistiono. 1992. Iktiologi, Suatu Pedoman Kerja Laboratorium. IPB. $344 \mathrm{hlm}$.

Afiati, N. 2005. Karakteristik Pertumbuhan Allometri Cangkang Kerang Darah Anadara indica (L.) (Bivalvia:Arcidae). Jurnal Saintek Perikanan Vol.1, 2005: 45-52.

Almonacid, E,. Hernandes,. V. Angelo S. Del pino and Castro, J. J. 2009. Sex Identification and Biomass Reconstruction from the Cuttlebone of Sepia officinalis. Marine Biological Association of the United Kingdom. Marine Biodiversity Records. Vol.2 page 1-4

Appannasastry, Y. 1989. Length-weight Relationship in the Cuttlefish Sepiella inermis Orbigny of Kakinada Coast. India. $2 \mathrm{hlm}$.

Bello, G. and Paparella, P. 2003. Scar-Bearing Cuttlebones in Wild-Collected Sepia Orbignyana (Cephalopoda: Sepiidae) and the Effects of Scar Occurrence on Morphometric Relationships. hlm. 1-6

Bister, T.J., D.W. Willis, M.L. Brown, S.M. Jordan, R.M. Neumann, M.C. Quist, C.S. Guy. 2000. Proposed Standard Weight (Ws) Equations and Standard Length Categories for Warm water Nongame and Riverine Fish Species. North American Journal of Fisheries Management. 20:570574.

Effendie, I. 2002. Biologi Perikanan. Yayasan Pustaka Nusatama, Yogyakarta. 97 hlm.

Froese, R. 2006. Cube Llaw, Condition Factor and Weight Length Relationship: History, Meta-Analysis and Recommendations. Journal of Applied Ichthyology, 22: 241-253.

Jennings, S, M. J. Kaiser, J. D. Reynolds. 2001. Marine Fishery Ecology. Blackwell Sciences, Oxford. 432 p.

Kier. 1988. The Arrangement and Function of Molluscan Muscle. The Mollusca, vol.11. Form and Function. by Academic Press. Inc. 211-252.

Kier, W. M. 1989. The Fin Musculature of Cuttlefish and Squid (Mollusca, Cephalopoda): Morphology and Mechanics. J. Zool. Lond. 217, 23-38.

Merta, I. G. S. 1993. Hubungan Panjang Berat dan Faktor Kondisi Ikan Lemuru, Sardinella lemuru Bleeker, 1853 dari Perairan Selat Bali. Jur. Pen. Per. Laut ( 73 ) : 35 - 44

Nateewathana, A. 1997. Systematics of Cephalopoda (Mollusca) of the Andaman Sea, Thailand. Ph.D. Dissertation. Institute of Biological Science, Faculty of Natural Science, University of Aarhus, Denmark. 343 hal.

Offem, B.O.,Y. Akegbejo-Samsons, I. T. Omoniyi. 2007.Biological assessment of Oreochromis niloticus (Pisces: Cichlidae: Linne:1958) in a Tropical flood Plain River. African Journal of Biotechnology, 6 (16): 1966-1971.

Rypel, A.L., T.J. Richter. 2008. Emperical Percentile Standard Weight Equation for the Blacktail Redhorse. North American Journal of Fisheries Management, 28: 1843-1846.

Sudjoko, B. 1988. Cumi-cumi (Cephalopoda, Molusca) sebagai Salah Satu Bahan Makanan dari Laut. Oseana XII (3): 97-107.

Sundaram, S., and Khan, M,. Z. 2011. Biology of the Spineless Cuttlefish Sepiella inermis (Orbigny, 1948) from Mumbai Waters. Indian J. Fish., 58(2) : 7-13.

Suryana. 2010. Metodologi Penelitian. Buku Ajar Perkuliahan UPI. Tidak diterbitkan.

Unnithan, K. A. 1974. Observations on the Biology of Cuttlefish Sepiella inermis at Mandapam. India. 11 hlm. 